九州大学学術情報リポジトリ

Kyushu University Institutional Repository

\title{
Synthesis and Insect Growth Regulating Activity of Ethyl Meta-Substituted Benzoates
}

Kim, In-Hae

Laboratory of Pesticide Chemistry, Division of Plant Protection, Department of Applied Genetics and Pest Management, Gradiage School of Bioresource and Bioenvironmental Sciences, Kyushu University

\section{Kuwano, Ei ichi}

Laboratory of Pesticide Chemistry, Division of Plant Protection, Department of Applied Genetics and Pest Management, Faculty of Agriculture, Kyushu University

https://doi.org/10.5109/24401

出版情報: 九州大学大学院農学研究院紀要. 45 (2)，pp.509-518，2001-02-28. Kyushu University バージョン：

権利関係 : 
J. Fac. Agr., Kyushu Univ., 45 (2), 509-518 (2001)

\title{
Synthesis and Insect Growth Regulating Activity of Ethyl Meta-Substituted Benzoates
}

\author{
In-Hae Kim* and Eiichi Kuwano** \\ Laboratory of Pesticide Chemistry, Division of Plant Protection, Department of Applied \\ Genetics and Pest Management, Faculty of Agriculture, Kyushu University, \\ Fukuoka 812-8581, Japan \\ (Received October 6, 2000 and accepted November 10, 2000)
}

\begin{abstract}
Twenty-one ethyl meta-substituted benzoates were synthesized and examined their effects on larval growth and molting of the silkworm, Bombyx mori. Of the compounds tested, only 2-(3-ethoxycarbonylphenoxy)ethyl 2-methyl-5-pyridyl ether (21) induced precocious metamorphosis when applied to $24-\mathrm{hr}$ old $3 \mathrm{rd}$-instar larvae. In contrast to ethyl 4-[2-( $t$-butylcarbonyloxy)butoxy]benzoate (ETB), a juvenile hormone antagonist, compound $\mathbf{2 1}$ showed precocious metamorphosis-inducing activity at a high dose of $100 \mu \mathrm{g}$. Compound $\mathbf{2 1}$ as well as ETB significantly prolonged the duration of the larval period. Preliminary structure-activity relationship studies indicated that the presence of a methyl substituent on the 6-position of 3-pyridine ring was important for precocious metamorphosis-inducing activity.
\end{abstract}

\section{INTRODUCTION}

It is well known that precocious metamorphosis is induced by allatectomy or juvenile hormone (JH) deficiency caused by anti-JH agents such as precocenes, fluoromevalonate (FMev), ethyl (E)-3-methyl-2-dodecenoate (EMD), and ethyl 4-[2-( $t$-butylcarbonyloxy)butoxy]benzoate (ETB) (Staal, 1986). Among them, ETB has been found to show JH-like activity as well as anti-JH activity for Manduca sexta (Staal, 1982) and Bombyx mori (Kiguchi et al., 1984), depending on the dose applied; low doses of ETB induced anti-JH activity, but as the dose increasing, JH-like activity was observed. Edwards et al. (1983) have reported that application of ETB resulted in a true reduction of endogenous $\mathrm{JH}$ titers in Manduca sexta larvae, probably due to the inhibition of JH biosynthesis either directly or indirectly. They have proposed the existence of negative-feedback control of JH biosynthesis. However, the exact mode of action of ETB is still unknown.

We have focused on ETB as a lead compound for the development of a new anti-JH agent, and found that ethyl 3-[2-( $t$-butylcarbonyloxy)butoxy]benzoate (meta-ETB) induced precocious metamorphosis in the 3 rd instar larvae of Bombyx mori at both low and high doses (Kuwano et al., 1988). To discover more effective anti-JH agents we synthesized additional ethyl meta-substituted benzoates and evaluated their effects on larval growth and molting in B. mori. In this paper we report the syntheses and struc-

\footnotetext{
* Laboratory of Pesticide Chemistry, Division of Plant Protection, Department of Applied Genetics and Pest Management, Graduate School of Bioresource and Bioenvironmental Sciences, Kyushu University

** Corresponding author (E-mail: ekuwano@agr.kyushu-u.ac.jp)
} 


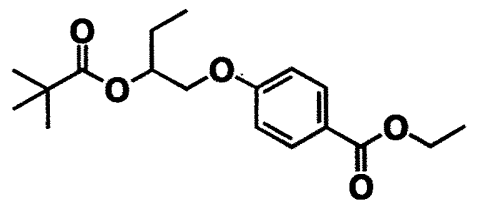

ETB<smiles>CCOC(=O)c1cccc(OCC(CC)OC(=O)C(C)(C)C)c1</smiles>

meta-ETB

ture--activity relationships of a new series of meta-ETB analogs.

\section{MATERIALS AND METHODS}

\section{Synthesis}

All melting points (mp) are uncorrected. ${ }^{1} \mathrm{H}-\mathrm{NMR}$ spectra were recorded on JNM-EX400 spectrometer with tetramethylsilane as an internal standard and all samples were prepared in deuterochloroform.

Ethyl 3-(4-phenoxybenzyloxy)benzoate (1)

To a solution of 4-phenoxybenzyl alcohol $(1.50 \mathrm{~g}, 7.5 \mathrm{mmol})$ in dichloromethane was added thionyl chloride $(0.65 \mathrm{ml}, 9.0 \mathrm{mmol})$ at room temperature. After stirring for $2 \mathrm{hr}$, to the reaction mixture was added water $(20 \mathrm{ml})$. The product was extracted with ether, dried over $\mathrm{Na}_{2} \mathrm{SO}_{4}$, and concentrated to afford crude 4-phenoxybenzyl chloride $(1.31 \mathrm{~g}$, $80 \%)$. To a suspension of sodium hydride $(0.29 \mathrm{~g}, 7.2 \mathrm{mmol})$ in dimethylformamide (DMF, $10 \mathrm{ml}$ ) was added ethyl 3-hydroxybenzoate $(1.0 \mathrm{~g}, 6.0 \mathrm{mmol})$ and the mixture was stirred for 30 minutes at room temperature. To the mixture was added the above chloride. After stirring for $5 \mathrm{hr}$, to the reaction mixture was added water $(10 \mathrm{ml})$ and the product was extracted with ether. The ether solution was washed with brine, dried over $\mathrm{Na}_{2} \mathrm{SO}_{4}$, and concentrated to dryness. The residue was purified by column chromatography on silica gel eluting with hexane and ethyl acetate (5:1) to afford $\mathbf{1}(1.25 \mathrm{~g}, 60 \%)$ as an oil. ${ }^{1} \mathrm{H}-\mathrm{NMR} \delta: 1.39(3 \mathrm{H}, \mathrm{t}, J=7.3 \mathrm{~Hz}), 4.37(2 \mathrm{H}, \mathrm{q}, J=7.3 \mathrm{~Hz}), 5.06(2 \mathrm{H}, \mathrm{s}), 7.13-7.66$ $(13 \mathrm{H}, \mathrm{m})$.

Compounds $\mathbf{2}$ and $\mathbf{3}$ were prepared in the same manner as $\mathbf{1}$ by using the corresponding chloride instead of 4-phenoxybenzyl chloride.

Ethyl 3-(4-phenylbenzyloxy)benzoate (2). mp 93-94 ${ }^{\circ} \mathrm{C} .{ }^{1} \mathrm{H}-\mathrm{NMR} \delta: 1.40(3 \mathrm{H}, \mathrm{t}$, $J=7.3 \mathrm{~Hz}), 4.38(2 \mathrm{H}, \mathrm{q}, J=7.3 \mathrm{~Hz}), 5.15(2 \mathrm{H}, \mathrm{s}), 7.23-7.64(13 \mathrm{H}, \mathrm{m})$.

Ethyl 3-(4-benzyloxybenzyloxy)benzoate (3). mp $60^{\circ} \mathrm{C} .{ }^{1} \mathrm{H}-\mathrm{NMR} \delta: 1.39(3 \mathrm{H}, \mathrm{t}$, $J=7.3 \mathrm{~Hz}), 4.37(2 \mathrm{H}, \mathrm{q}, J=6.8 \mathrm{~Hz}), 5.03(2 \mathrm{H}, \mathrm{s}), 5.08(2 \mathrm{H}, \mathrm{s}), 7.00(2 \mathrm{H}, \mathrm{d}, 8.8 \mathrm{~Hz})$, 7.14-7.45 (9H, m), 7.64-7.69 (2 H, m).

Ethyl 3-octyloxybenzoate (8)

Ethyl 3-hydroxybenzoate $(1.0 \mathrm{~g}, 6.0 \mathrm{mmol})$ was added to a stirring suspension of $\mathrm{NaH}$ $(0.29 \mathrm{~g}, 7.2 \mathrm{mmol})$ in DMF at room temperature. After stirring for $30 \mathrm{~min}$, to the reaction mixture was added 1-iodooctane $(1.16 \mathrm{~g}, 6.0 \mathrm{mmol})$. Then $10 \mathrm{ml}$ of water was added to the reaction after $5 \mathrm{hr}$ and the product was extracted with ether. The ether solution was washed with brine, dried over $\mathrm{Na}_{2} \mathrm{SO}_{4}$ and concentrated. The residue was purified by column chromatography on silica gel eluting with hexane and ethyl acetate (3:1) to afford $\mathbf{8}$ 
$(1.0 \mathrm{~g}, 60 \%)$ as an oil. ${ }^{1} \mathrm{H}-\mathrm{NMR} \delta: 0.87(3 \mathrm{H}, \mathrm{t}, J=6.8 \mathrm{~Hz}), 1.29-1.57(13 \mathrm{H}, \mathrm{m}), 1.72-1.77$ $(2 \mathrm{H}, \mathrm{m}), 3.98(2 \mathrm{H}, \mathrm{t}, J=6.8 \mathrm{~Hz}), 4.35(2 \mathrm{H}, \mathrm{q}, J=7.3 \mathrm{~Hz}), 7.07(1 \mathrm{H}, \mathrm{dd}, J=7.8$ and $1.5 \mathrm{~Hz})$, $7.24(1 \mathrm{H}, \mathrm{t}, J=7.8 \mathrm{~Hz}), 7.53(1 \mathrm{H}, \mathrm{d}, J=1.5 \mathrm{~Hz}), 7.60(1 \mathrm{H}, \mathrm{d}, J=7.8 \mathrm{~Hz})$.

Compounds 4-7 and 9-10 were prepared in the same manner as 8 by using the corresponding bromide or iodide.

Ethyl 3-[2-(4-phenoxyphenoxy)ethoxy]benzoate (4). mp $75^{\circ} \mathrm{C} .{ }^{1} \mathrm{H}-\mathrm{NMR} \delta: 1.39$ $(3 \mathrm{H}, \mathrm{t}, J=7.3 \mathrm{~Hz}), 4.33-4.37(6 \mathrm{H}, \mathrm{m}), 6.94-7.64(13 \mathrm{H}, \mathrm{m})$.

Ethyl 3-[6-(4-phenoxyphenoxy)hexyloxy]benzoate (5). mp 85-86 ${ }^{\circ} \mathrm{C} .{ }^{1} \mathrm{H}-\mathrm{NMR} \delta$ : $1.39(3 \mathrm{H}, \mathrm{t}, J=7.3 \mathrm{~Hz}), 1.55-1.59(4 \mathrm{H}, \mathrm{m}), 1.81-1.84(4 \mathrm{H}, \mathrm{m}), 3.96(2 \mathrm{H}, \mathrm{t}, J=6.4 \mathrm{~Hz}), 4.02$ $(2 \mathrm{H}, \mathrm{t}, J=6.4 \mathrm{~Hz}), 4.37(2 \mathrm{H}, \mathrm{q}, J=7.3 \mathrm{~Hz}), 6.86-7.35(11 \mathrm{H}, \mathrm{m}), 7.56(1 \mathrm{H}, \mathrm{d}, J=1.5 \mathrm{~Hz})$, $7.63(1 \mathrm{H}, \mathrm{d}, J=6.3 \mathrm{~Hz})$.

Ethyl 3-[2-(4-ethylphenoxy)ethoxy]benzoate (6). mp 50-53 ${ }^{\circ} \mathrm{C} .{ }^{1} \mathrm{H}-\mathrm{NMR} \delta: 1.21(3 \mathrm{H}$, $\mathrm{t}, J=7.3 \mathrm{~Hz}), 1.39(3 \mathrm{H}, \mathrm{t}, J=7.3 \mathrm{~Hz}), 2,59(2 \mathrm{H}, \mathrm{q}, J=7.3 \mathrm{~Hz}), 4.28-4.43(6 \mathrm{H}, \mathrm{m}), 6.88(2 \mathrm{H}$, d, $J=7.8 \mathrm{~Hz}), 7.07-7.19(3 \mathrm{H}, \mathrm{m}), 7.33(1 \mathrm{H}, \mathrm{t}, J=7.3 \mathrm{~Hz}), 7.58-7.70(2 \mathrm{H}, \mathrm{m})$.

Ethyl 3-[6-(4-ethylphenoxy)hexyloxy]benzoate (7). ${ }^{1} \mathrm{H}-\mathrm{NMR} \quad \delta: 1.20(3 \mathrm{H}, \mathrm{t}$, $J=7.3 \mathrm{~Hz}), 1.39(3 \mathrm{H}, \mathrm{t}, J=7.3 \mathrm{~Hz}), 1.48-1.64(4 \mathrm{H}, \mathrm{m}), 1.79-1.91(4 \mathrm{H}, \mathrm{m}), 2.54-2.61(2 \mathrm{H}$, m), $3.95(2 \mathrm{H}, \mathrm{t}, J=6.3 \mathrm{~Hz}), 4.01(2 \mathrm{H}, \mathrm{t}, J=6.3 \mathrm{~Hz}), 4.37(2 \mathrm{H}, \mathrm{q}, J=7.3 \mathrm{~Hz})), 6.82(2 \mathrm{H}, \mathrm{m})$, $7.05-7.13(3 \mathrm{H}, \mathrm{m}), 7.32(1 \mathrm{H}, \mathrm{t}, J=7.8 \mathrm{~Hz}), 7.56(1 \mathrm{H}, \mathrm{d}, J=1.5 \mathrm{~Hz}), 7.62(1 \mathrm{H}, \mathrm{d}, J=6.4 \mathrm{~Hz})$. Ethyl 3-hexyloxybenzoate (9). ${ }^{1} \mathrm{H}-\mathrm{NMR} \delta: 0.91(3 \mathrm{H}, \mathrm{t}, J=6.8 \mathrm{~Hz}), 1.34-1.49(9 \mathrm{H}, \mathrm{m})$, $1.76-1.84(2 \mathrm{H}, \mathrm{m}), 4.00(2 \mathrm{H}, \mathrm{t}, J=6.8 \mathrm{~Hz}), 4.37(2 \mathrm{H}, \mathrm{q}, J=7.3 \mathrm{~Hz}), 7.08(1 \mathrm{H}, \mathrm{dd}, J=7.8$ and $1.5 \mathrm{~Hz}), 7.32(1 \mathrm{H}, \mathrm{t}, J=7.8 \mathrm{~Hz}), 7.55(1 \mathrm{H}, \mathrm{d}, J=1.5 \mathrm{~Hz}), 7.61(1 \mathrm{H}, \mathrm{d}, J=7.8 \mathrm{~Hz})$.

Ethyl 3-(4-t-butylbenzyloxy)benzoate (10). ${ }^{1} \mathrm{H}-\mathrm{NMR} \delta: 1.29-1.42(12 \mathrm{H}, \mathrm{m}), 4.37$ $(2 \mathrm{H}, \mathrm{q}, J=7.3 \mathrm{~Hz}), 5.06(2 \mathrm{H}, \mathrm{s}), 7.17(1 \mathrm{H}, \mathrm{dd}, J=7.8$ and $1.5 \mathrm{~Hz}), 7.32-7.43(5 \mathrm{H}, \mathrm{m})$, $7.64-7.66(2 \mathrm{H}, \mathrm{m})$.

2-(3-Ethoxycarbonylphenoxy)ethyl 2-methyl-5-pyridyl ether (21)

A mixture of ethyl 3 -hydroxybenzoate $(1.50 \mathrm{~g}, 9 \mathrm{mmol}), \mathrm{K}_{2} \mathrm{CO}_{3}(3.74 \mathrm{~g}, 27 \mathrm{mmol})$, and 1,2 -dibromoethane $(8.48 \mathrm{~g}, 51 \mathrm{mmol})$ in DMF was stirred for $10 \mathrm{hr}$ at room temperature. Then water was added to the reaction mixture, and the product was extracted with ether. The ether solution was washed with brine, dried over $\mathrm{Na}_{2} \mathrm{SO}_{4}$ and concentrated to dryness. The residue was purified by column chromatography on silica gel eluting with hexane and ethyl acetate (3:1) to afford ethyl 3-(2-bromoethoxy)benzoate (1.23g, 50\%). To a suspension of sodium hydride $(0.14 \mathrm{~g}, 3.5 \mathrm{mmol})$ in DMF $(10 \mathrm{ml})$ was added 2-methyl-5-hydroxypyridine $(0.32 \mathrm{~g}, 2.9 \mathrm{mmol})$ and the mixture was stirred for 30 minutes at room temperature. To the mixture was added the above bromide $(0.80 \mathrm{~g}$, $2.9 \mathrm{mmol})$. After stirring for $5 \mathrm{hr}$, to the reaction mixture was added water $(10 \mathrm{ml})$ and the product was extracted with ether. The ether solution was washed with brine and the product was extracted with $20 \mathrm{ml}$ of $1 \mathrm{~N} \mathrm{H}_{2} \mathrm{SO}_{4}$ solution from the organic layer. After neutralizing the acidic aqueous solution with $\mathrm{K}_{2} \mathrm{CO}_{3}$, the product was extracted with ether again. The ether solution was washed with brine, dried over $\mathrm{Na}_{2} \mathrm{SO}_{4}$, and concentrated to afford $21(0.44 \mathrm{~g}, 57 \%)$ as a white solid, mp $135^{\circ} \mathrm{C}$. ${ }^{1} \mathrm{H}-\mathrm{NMR} \delta: 1.40(3 \mathrm{H}, \mathrm{t}, J=7.3 \mathrm{~Hz})$, $2.51(3 \mathrm{H}, \mathrm{s}), 4.35-4.41(6 \mathrm{H}, \mathrm{m}), 7.08(1 \mathrm{H}, \mathrm{d}, J=8.8 \mathrm{~Hz}), 7.14-7.20(2 \mathrm{H}, \mathrm{m}), 7.36(1 \mathrm{H}, \mathrm{t}$, $J=7.8 \mathrm{~Hz}), 7.62(1 \mathrm{H}, \mathrm{d}, J=2.0 \mathrm{~Hz}), 7.67-7.69(1 \mathrm{H}, \mathrm{d}, J=7.8 \mathrm{~Hz}), 8.25(1 \mathrm{H}, \mathrm{d}, J=2.9 \mathrm{~Hz})$.

Compounds 12-20 were prepared in the same manner as that used for compound $\mathbf{2 1}$ from ethyl 3-(2-bromoethoxy)benzoate or 3-(3-brompropyloxy)benzoate.

2-(3-Ethoxycarbonylphenoxy)ethyl 2-pyridyl ether (12). mp $48-49^{\circ} \mathrm{C} .{ }^{1} \mathrm{H}-\mathrm{NMR} \delta$ : 
$1.39(3 \mathrm{H}, \mathrm{t}, J=7.3 \mathrm{~Hz}), 4.31-4.41(6 \mathrm{H}, \mathrm{m}), 6.18(1 \mathrm{H}, \mathrm{t}, J=6.8 \mathrm{~Hz}), 6.58(1 \mathrm{H}, \mathrm{d}, J=9.3 \mathrm{~Hz})$, $7.05(1 \mathrm{H}, \mathrm{dd}, J=8.8$ and $2.4 \mathrm{~Hz}), 7.25-7.46(3 \mathrm{H}, \mathrm{m}), 7.52(1 \mathrm{H}, \mathrm{s}), 7.64(1 \mathrm{H}, \mathrm{d}, J=7.8 \mathrm{~Hz})$. 2-(3-Ethoxycarbonylphenoxy)ethyl 3-pyridyl ether (13). mp 50-51 ${ }^{\circ} \mathrm{C}$. ${ }^{1} \mathrm{H}-\mathrm{NMR} \delta$ : $1.40(3 \mathrm{H}, \mathrm{t}, J=7.3 \mathrm{~Hz}), 4.34-4.43(6 \mathrm{H}, \mathrm{m}), 7.15(1 \mathrm{H}, \mathrm{dd}, J=7.8$ and $1.5 \mathrm{~Hz}), 7.22-7.29$ $(2 \mathrm{H}, \mathrm{m}), 7.36(1 \mathrm{H}, \mathrm{t}, J=7.8 \mathrm{~Hz}), 7.62(1 \mathrm{H}, \mathrm{d}, J=1.5 \mathrm{~Hz}), 7.68(1 \mathrm{H}, \mathrm{d}, J=6.8 \mathrm{~Hz}), 8.25(1 \mathrm{H}$, $\mathrm{d}, J=4.4 \mathrm{~Hz}), 8.37(1 \mathrm{H}, \mathrm{d}, J=2.5 \mathrm{~Hz})$.

2-(3-Ethoxycarbonylphenoxy)ethyl 4-pyridyl ether (14). mp 50-55 ${ }^{\circ} \mathrm{C} .{ }^{1} \mathrm{H}-\mathrm{NMR} \delta$ : $1.40(3 \mathrm{H}, \mathrm{t}, J=7.3 \mathrm{~Hz}), 4.34-4.44(6 \mathrm{H}, \mathrm{m}), 6.89(2 \mathrm{H}, \mathrm{d}, J=5.4 \mathrm{~Hz}), 7.14(1 \mathrm{H}, \mathrm{dd}, J=8.8$ and $2.4 \mathrm{~Hz}), 7.37(1 \mathrm{H}, \mathrm{t}, J=7.8 \mathrm{~Hz}), 7.62(1 \mathrm{H}, \mathrm{s}), 7.68(1 \mathrm{H}, \mathrm{d}, J=6.8 \mathrm{~Hz}), 8.47(2 \mathrm{H}, \mathrm{brs})$

3-(3-Ethoxycarbonylphenoxy)propyl 2-pyridyl ether (15). ${ }^{1} \mathrm{H}-\mathrm{NMR} \delta: 1.40(3 \mathrm{H}, \mathrm{t}$, $J=7.3 \mathrm{~Hz}), 2.29(2 \mathrm{H}$, quint, $J=5.9 \mathrm{~Hz}), 4.03(2 \mathrm{H}, \mathrm{t}, J=5.9 \mathrm{~Hz}), 4.16(2 \mathrm{H}, \mathrm{t}, J=7.3 \mathrm{~Hz}), 4.37$ $(2 \mathrm{H}, \mathrm{q}, J=7.3 \mathrm{~Hz}), 6.12(1 \mathrm{H}, \mathrm{t}, J=6.8 \mathrm{~Hz}), 6.58(1 \mathrm{H}, \mathrm{d}, J=9.3 \mathrm{~Hz}), 7.08(1 \mathrm{H}, \mathrm{d}, J=5.9 \mathrm{~Hz})$, $7.25-7.37(3 \mathrm{H}, \mathrm{m}), 7.55(1 \mathrm{H}, \mathrm{d}, J=1.5 \mathrm{~Hz}), 7.65(1 \mathrm{H}, \mathrm{d}, J=6.3 \mathrm{~Hz})$.

3-(3-Ethoxycarbonylphenoxy)propyl 3-pyridyl ether (16). ' $\mathrm{H}-\mathrm{NMR} \delta: 1.39(3 \mathrm{H}, \mathrm{t}$, $J=7.3 \mathrm{~Hz}), 2.30(2 \mathrm{H}$, quint, $J=5.9 \mathrm{~Hz}), 4.16-4.27(4 \mathrm{H}, \mathrm{m}), 4.37(2 \mathrm{H}, \mathrm{q}, J=7.3 \mathrm{~Hz}), 7.10$ $(1 \mathrm{H}, \mathrm{dd}, J=7.8$ and $2.0 \mathrm{~Hz}), 7.20-7.28(2 \mathrm{H}, \mathrm{m}), 7.34(1 \mathrm{H}, \mathrm{t}, J=7.8 \mathrm{~Hz}), 7.58(1 \mathrm{H}, \mathrm{d}$, $J=2.0 \mathrm{~Hz}), 7.64(1 \mathrm{H}, \mathrm{d}, J=7.8 \mathrm{~Hz}), 8.21(1 \mathrm{H}, \mathrm{d}, J=5.9 \mathrm{~Hz}), 8: 32(1 \mathrm{H}, \mathrm{d}, J=2.0 \mathrm{~Hz})$.

3-(3-Ethoxycarbonylphenoxy)propyl 4-pyridyl ether (17). ' $\mathrm{H}-\mathrm{NMR} \delta: 1.40(3 \mathrm{H}, \mathrm{t}$, $J=7.3 \mathrm{~Hz}), 2.34(2 \mathrm{H}$, quint, $J=5.9 \mathrm{~Hz}), 4.20-4.40(6 \mathrm{H}, \mathrm{m}), 6.80(2 \mathrm{H}, \mathrm{d}, J=5.4 \mathrm{~Hz}), 7.07$ $(1 \mathrm{H}, \mathrm{dd}, J=8.8$ and $2.4 \mathrm{~Hz}), 7.37(1 \mathrm{H}, \mathrm{t}, J=7.8 \mathrm{~Hz}), 7.62(1 \mathrm{H}, \mathrm{s}), 7.68(1 \mathrm{H}, \mathrm{d}, J=6.8 \mathrm{~Hz})$ $8.41(2 \mathrm{H}$, brs $)$.

1-[2-(3-Ethoxycarbonylphenoxy)ethyl]-2-(4-pyridyl)imidazole (18). ${ }^{1} \mathrm{H}-\mathrm{NMR} \delta$ : $1.39(3 \mathrm{H}, \mathrm{t}, J=7.3 \mathrm{~Hz}), 4.26-4.52(6 \mathrm{H}, \mathrm{m}), 7.00-7.09(3 \mathrm{H}, \mathrm{m}), 7.34(1 \mathrm{H}, \mathrm{td}, J=6.4$ and $2.0 \mathrm{~Hz}), 7.63(1 \mathrm{H}, \mathrm{dd}, J=6.4$ and $1.5 \mathrm{~Hz}), 7.67(1 \mathrm{H}, \mathrm{d}, J=7.3 \mathrm{~Hz}), 7.81(1 \mathrm{H}, \mathrm{dd}, J=2.9$ and $1.5 \mathrm{~Hz}), 8.59(1 \mathrm{H}, \mathrm{d}, J=4.9 \mathrm{~Hz}), 8.72(1 \mathrm{H}, \mathrm{d}, J=4.9 \mathrm{~Hz})$.

2-(3-Ethoxycarbonylphenoxy)ethyl 6-methyl-2-pyridyl ether (19). mp $83^{\circ} \mathrm{C}$. ${ }^{1} \mathrm{H}-\mathrm{NMR} \quad \delta: 1.39(3 \mathrm{H}, \mathrm{t}, J=7.3 \mathrm{~Hz}), 2.54(3 \mathrm{H}, \mathrm{s}), 4.32-4.46(6 \mathrm{H}, \mathrm{m}), 6.04(1 \mathrm{H}, \mathrm{d}$, $J=6.8 \mathrm{~Hz}), 6.45(1 \mathrm{H}, \mathrm{d}, J=8.8 \mathrm{~Hz}), 7.04(1 \mathrm{H}, \mathrm{dd}, J=8.8$ and $2.4 \mathrm{~Hz}), 7.21-7.32(2 \mathrm{H}, \mathrm{m})$, $7.51(1 \mathrm{H}, \mathrm{d}, J=1.5 \mathrm{~Hz}), 7.63(1 \mathrm{H}, \mathrm{d}, J=7.8 \mathrm{~Hz})$.

5-Chloro-3-pyridyl 2-(3-ethoxycarbonylphenoxy)ethyl ether (20). ' $\mathrm{H}-\mathrm{NMR} \delta: 1.40$ $(3 \mathrm{H}, \mathrm{t}, J=7.3 \mathrm{~Hz}), 4.36-4.43(6 \mathrm{H}, \mathrm{m}), 7.14(1 \mathrm{H}, \mathrm{dd}, J=8.8$ and $2.4 \mathrm{~Hz}), 7.29(1 \mathrm{H}, \mathrm{d}$, $J=2.4 \mathrm{~Hz}), 7.37(1 \mathrm{H}, \mathrm{t}, J=7.8 \mathrm{~Hz}), 7.61(1 \mathrm{H}, \mathrm{s}), 7.69(1 \mathrm{H}, \mathrm{d}, J=7.8 \mathrm{~Hz}), 8.23(1 \mathrm{H}, \mathrm{d}$, $J=1.5 \mathrm{~Hz}), 8.27(1 \mathrm{H}, \mathrm{d}, J=2.4 \mathrm{~Hz})$

Ethyl 3-[2-(t-butylcarbonyloxy)-2-phenylethoxy]benzoate (11)

To a suspension of sodium hydride $(0.48 \mathrm{~g}, 12 \mathrm{mmol})$ in DMF (10 ml) was added ethyl 3-hydroxybenzoate $(1.67 \mathrm{~g}, 11 \mathrm{mmol})$ and the mixture was stirred for 20 minutes at room temperature. To the mixture was added a solution of 2-bromoacetophenone (2.00 g, $11 \mathrm{mmol}$ ) in $5 \mathrm{ml}$ of DMF. After stirring for $10 \mathrm{hr}$, water was added to the reaction mixture and the product was extracted with ether. The ether solution was washed with brine, dried over $\mathrm{Na}_{2} \mathrm{SO}_{4}$, and concentrated. The residue was purified by column chromatography on silica gel eluting with hexane and ethyl acetate (3:1) to afford phenylcarbonylmethyl 3-ethoxycarbonylphenyl ether $(2.29 \mathrm{~g}, 80 \%)$. To this ketone compound $(2.29 \mathrm{~g}, 8.1 \mathrm{mmol})$ in ethanol $(20 \mathrm{ml})$ was added $\mathrm{NaBH}_{4}(0.91 \mathrm{~g}, 2.4 \mathrm{mmol})$ at $0{ }^{\circ} \mathrm{C}$. After stirring for $3 \mathrm{hr}$, water was added to the reaction mixture and the alcohol product was extracted with ether. The ether solution was washed with brine, and dried over $\mathrm{Na}_{2} \mathrm{SO}_{4}$. 
Concentration of the solvent gave crude ethyl 3-(2-hydroxy-2-phenylethoxy)benzoate $(2.30 \mathrm{~g}, 100 \%)$. To a solution of the alcohol $(0.10 \mathrm{~g}, 0.42 \mathrm{mmol}), 4$-dimethylaminopyridine $(0.051 \mathrm{~g}, 0.42 \mathrm{mmol}$; DMAP) and triethylamine $(0.042 \mathrm{~g}, 0.42 \mathrm{mmol})$ in dichloromethane was added pivaloyl chloride $(0.050 \mathrm{~g}, 0.42 \mathrm{mmol})$ with stirring at room temperature. After stirring for $10 \mathrm{hr}$, the product (11) was obtained by same purification manner to that described above in $40 \%$ yield $(0.062 \mathrm{~g})$ as a yellowish oil. ' $\mathrm{H}-\mathrm{NMR} \delta: 1.22(9 \mathrm{H}, \mathrm{s}), 1.39$ $(3 \mathrm{H}, \mathrm{t}, J=7.3 \mathrm{~Hz}), 4.21-4.28(2 \mathrm{H}, \mathrm{m}), 4.37(2 \mathrm{H}, \mathrm{q}, J=7.3), 6.13-6.17(1 \mathrm{H}, \mathrm{m}), 7.06-7.09$ $(1 \mathrm{H}, \mathrm{m}), 7.31-7.41(6 \mathrm{H}, \mathrm{m}), 7.53(1 \mathrm{H}, \mathrm{d}, J=2.9 \mathrm{~Hz}), 7.65(1 \mathrm{H}, \mathrm{d}, J=7.3 \mathrm{~Hz})$

Ethyl 4-[2-(t-butylcarbonyloxy)butoxy]benzoate (ETB)

A mixture of ethyl 4-hydroxybenzoate $(2.00 \mathrm{~g}, 12 \mathrm{mmol}), \mathrm{K}_{2} \mathrm{CO}_{3}(1.83 \mathrm{~g}, 13 \mathrm{mmol})$, and 1,2-butylene oxide $(1.74 \mathrm{~g}, 24 \mathrm{mmol})$ in acetonitrile was stirred at $60^{\circ} \mathrm{C}$ for $24 \mathrm{hr}$. After cooling the reaction mixture to room temperature, the product was extracted with ether. The ether solution was washed with $2 \mathrm{~N} \mathrm{NaOH}$ solution and brine, and dried over $\mathrm{Na}_{2} \mathrm{SO}_{4}$. Concentration of the solvent afforded ethyl 4-(2-hydroxybutoxy)benzoate $(1.33 \mathrm{~g}, 46 \%)$ as an oil. To a reaction mixture of the above alcohol $(1.33 \mathrm{~g}, 6.0 \mathrm{mmol})$, DMAP $(0.68 \mathrm{~g}, 6.0 \mathrm{mmol})$ and triethylamine $(0.57 \mathrm{~g}, 6.0 \mathrm{mmol})$ in dichloromethane was added pivaloyl chloride $(0.74 \mathrm{~g}, 6.1 \mathrm{mmol})$ with stirring at room temperature. After stirring for $4 \mathrm{hr}$ at room temperature, the product was extracted with ether, and the organic layer was washed with brine, dried over $\mathrm{Na}_{2} \mathrm{SO}_{4}$, and concentrated. The residue was purified by column chromatography on silica gel eluting with hexane and ethyl acetate (5:1) to afford ETB $(1.62 \mathrm{~g}, 95 \%)$ as an oil. ${ }^{1} \mathrm{H}-\mathrm{NMR} \delta: 0.97(3 \mathrm{H}, \mathrm{t}, J=6.8 \mathrm{~Hz})$, $1.20(9 \mathrm{H}, \mathrm{s}), 1.38(3 \mathrm{H}, \mathrm{t}, J=6.8 \mathrm{~Hz}), 1.75-1.77(2 \mathrm{H}, \mathrm{m}), 4.06(2 \mathrm{H}, \mathrm{d}, J=5.9 \mathrm{~Hz}), 4.34(2 \mathrm{H}$, q, $J=6.8 \mathrm{~Hz}), 5.13(1 \mathrm{H}, \mathrm{m}), 6.90(2 \mathrm{H}, \mathrm{d}, J=8.3 \mathrm{~Hz}), 7.98(2 \mathrm{H}, \mathrm{d}, J=8.3 \mathrm{~Hz})$.

\section{Biological evaluations}

B. mori (Shunrei $\times$ Shougetsu strain) larvae were reared on artificial diets as previously described (Yoshida et al., 2000). Test compounds in acetone solution (1-4 $\mu \mathrm{l}$ per larva) were applied topically to $24 \mathrm{~h}$-old $3 \mathrm{rd}$-instar larvae. The time required for ecdysis to 4 th and 5 th instar was recorded. The precocious metamorphosis--inducing activity was evaluated by spinning a cocoon and subsequent pupation or formation of larval-pupal intermediates from the 4 th-instar (penultimate) larval period.

\section{RESULTS AND DISCUSSION}

\section{Synthesis}

Fig. 1 shows the structures of synthesized compounds. Compounds 1-10 were prepared by reaction of the corresponding alkyl halide with ethyl 3-hydroxybenzoate as shown in Fig. 2 (A). Ethyl 3-[2-(t-butylcarbonyloxy)-2-phenylethoxy]benzoate (11) was synthesized by the procedure outlined in Fig. 2 (B). Alkylation of ethyl 3-hydroxybenzoate with 2 -bromoacetophenone, followed by reduction with sodium borohydride gave alcohol, which was esterified with pivaloyl chloride using 4-dimethylaminopyridine (DMAP) as a base to give 11. 3-Ethoxycarbonylphenyl pyridyl ethers 12-17 and 19-21 were prepared as illustrated in Fig. 2 (C). Reaction of ethyl 3-hydroxybenzoate with dibromoalkanes gave phenoxyalkyl bromides, which were treated with an appropriate hydroxypyridine in the presence of sodium hydride as a base in dimethylformamide to 
<smiles>CCOC(=O)c1cccc(O)c1</smiles>

$\mathbf{R}$

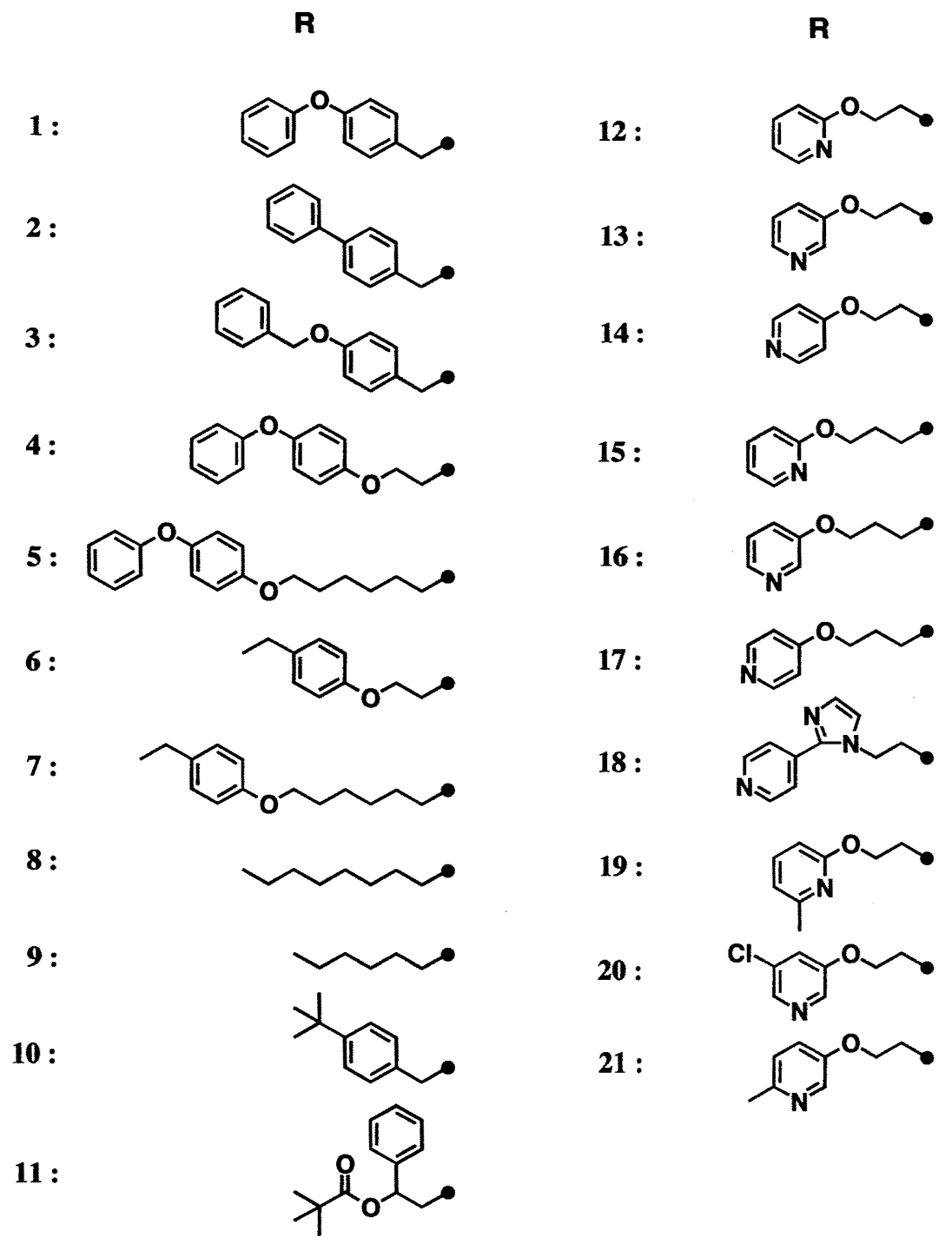

3 :

Fig. 1. Structures of synthesized ethyl meta-substituted benzoates 
(A)

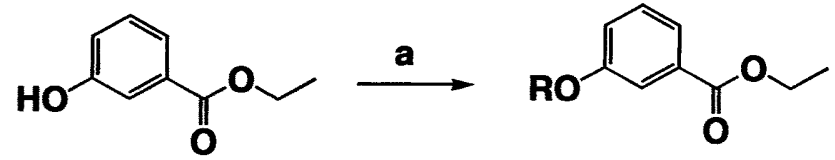

(B)<smiles>CCOC(=O)c1cccc(OCC(O)c2ccccc2)c1</smiles><smiles>CCOC(=O)c1cccc(OCC(OC(=O)C(C)(C)C)c2ccccc2)c1</smiles>

(C)

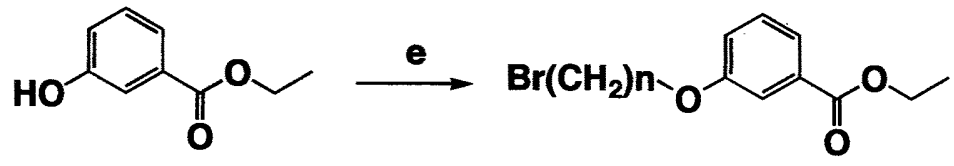<smiles>CCOCCCOc1cccc(C(=O)OCC)c1</smiles>

12-17, 19-21

(D)

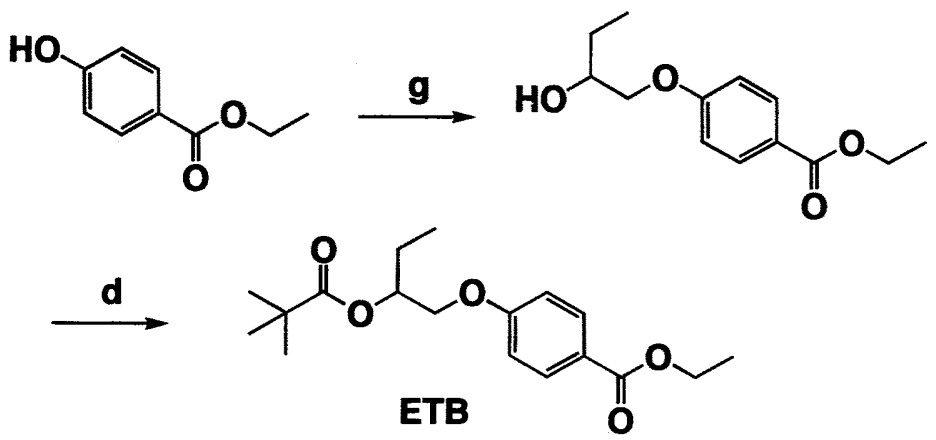

Fig. 2. Synthesis of ethyl meta-substituted benzoates

Reagents: (a) alkyl halide, $\mathrm{NaH}, \mathrm{DMF}$, (b) 2-bromoacetophenone, $\mathrm{NaH}, \mathrm{DMF}$, (c) $\mathrm{NaBH}_{4}, \mathrm{EtOH}$, (d) pivaloyl chloride, DMAP, triethylamine, $\mathrm{CH}_{2} \mathrm{Cl}_{2}$, (e) $\mathrm{Br}\left(\mathrm{CH}_{2}\right)_{n} \mathrm{Br}, \mathrm{K}_{2} \mathrm{CO}_{3}$, DMF, (f) hydroxypyridine, $\mathrm{NaH}$, DMF, (g) 1,2-butylene oxide, $\mathrm{K}_{2} \mathrm{CO}_{3}, \mathrm{CH}_{3} \mathrm{CN}$. 
afford pyridyl ethers. Imidazole analog $\mathbf{1 8}$ was similarly prepared from 2-(3-ethoxycarbonylphenoxy)ethyl bromide and 2-(4-pyridyl)imidazle (Baldwin et al., 1977) The synthesis of ETB was accomplished by the procedure outlined in Fig. 2 (D). Ethyl 4-hydroxybenzoate was treated with 1,2-butylene oxide in the presence of potassium carbonate as a base in acetonitrile to afford ethyl 4-(2-hydroxybutoxy)benzoate, which was esterified with pivaloyl chloride in the same manner as compound $\mathbf{1 1}$ to provide ETB.

\section{Biological activity}

ETB has been known to induce precocious metamorphosis in the silkworm when applied to 3 rd-instar larvae. In this case precocious metamorphosis always occurred in the 4 th (penultimate) larval stage. When ETB was applied to 4 th-instar larvae, none of the treated larvae showed any sign of precocious metamorphosis, and all of the treated larvae molted into the normal 5 th-instar (Kiguchi et al., 1984 and Kuwano et al., 1988). Since 24-hr old 3 rd-instar larvae was more susceptible to ETB than newly molted larvae (Kuwano et al., 1988), we examined the effects of ethyl meta-substituted benzoates on larval growth, molting and metamorphosis against 24-hr old 3 rd-instar larvae.

Although the strain of the silkworm used in this experiment was not susceptible to ETB, clear induction of precocious metamorphosis was observed by ETB treatment (Table 1). As previously reported (Kuwano et al., 1988), the activity of ETB to induce precocious metamorphosis did not correlate with the applied dose; ETB at $10 \mu \mathrm{g}$ exhibited some activity, while at a high dose of $100 \mu \mathrm{g}$ none of the treated larvae metamorphosed into precocious pupae. Among the compounds shown in Fig. 1, only 2-(3-ethoxycarbonylphenoxy)-ethyl 2-methyl-5-pyridyl ether (21) induced precocious metamorphosis against 24 -hr old 3 rd-instar larvae, though very low activity. In contrast to ETB, compound $\mathbf{2 1}$ had activity at a high dose of $100 \mu \mathrm{g}$, but no activity at $10 \mu \mathrm{g}$.

Precocious metamorphosis induced by ETB and compound $\mathbf{2 1}$ was always accompanied by the prolongation of the larval period, similar to that induced by treatment with 1,5-substituted imidazoles (Kadono-Okuda et al., 1987) and 3-pyridine derivatives (Yoshida et al., 2000). Therefore, we observed the effects of ethyl meta-substituted benzoates on growth and 4 th ecdysis in the larvae, in which precocious metamorphosis could not be induced by the compound treatment.

A topical application of ETB at $10 \mu$ g slightly but significantly prolonged the duration of both $3 \mathrm{rd}$ and subsequent 4 th larval instar (Table 2). In control, the $3 \mathrm{rd}$ and 4 th larval period was 3.0 and 4.0 days on average, respectively, while ETB treatment resulted in 3.3 \pm 0.4 and $4.4 \pm 0.5$ days, respectively. ETB at $100 \mu \mathrm{g}$ clearly delayed the $3 \mathrm{rd}$ and 4 th ecdysis by 1 to 1.5 days, respectively, compared with the control period. However, it is

Table 1. Precocious metamorphosis-inducing activity of ETB and compound $\mathbf{2 1}$ against $24 \mathrm{~h}$-old $3 \mathrm{rd-instar} \mathrm{larvae}$

\begin{tabular}{cccc}
\hline \multirow{2}{*}{ Compound } & \multicolumn{2}{c}{ Activity (\%) } \\
\cline { 3 - 4 } & Dose $(\mu \mathrm{g} /$ /arva $)$ & 100 & 10 \\
\hline \multirow{2}{*}{ ETB } & & 0 & 10 \\
$\mathbf{2 1}$ & 5 & 0 \\
\hline
\end{tabular}


Table 2. Larval periods of the silkworm treated with ETB and ethyl meta-substituted benzoates

\begin{tabular}{crrr}
\hline \multirow{2}{*}{ Compound } & $\begin{array}{c}\text { Dose } \\
(\mu g / \text { larva })\end{array}$ & \multicolumn{2}{c}{$\begin{array}{c}\text { Larval period } \\
\text { (Days } \pm \text { S.D. })\end{array}$} \\
\cline { 3 - 4 } & 10 & $3.3 \pm 0.4^{\mathrm{a}}$ & $4.4 \pm 0.5^{\mathrm{a}}$ \\
\hline \multirow{2}{*}{ ETB } & 100 & $4.0 \pm 0.2^{\mathrm{a}}$ & $5.6 \pm 0.5^{\mathrm{a}}$ \\
& 10 & $3.1 \pm 0.3$ & $4.3 \pm 0.4^{\mathrm{a}}$ \\
$\mathbf{5}$ & 100 & $3.0 \pm 0.0$ & $4.3 \pm 0.4^{\mathrm{a}}$ \\
& 10 & $3.1 \pm 0.2$ & $4.1 \pm 0.3$ \\
$\mathbf{6}$ & 100 & $3.2 \pm 0.4$ & $4.7 \pm 0.6^{\mathrm{a}}$ \\
& 10 & $3.0 \pm 0.0$ & $4.2 \pm 0.4$ \\
$\mathbf{7}$ & 100 & $3.1 \pm 0.2$ & $4.4 \pm 0.5^{\mathrm{a}}$ \\
& & $3.0 \pm 0.0$ & $4.0 \pm 0.0$ \\
\hline
\end{tabular}

a Significant difference from the control value $(p<0.05)$.

Table 3. Larval periods of the silkworm treated with (3-ethoxycarbonylphenoxy)alkyl substituted pyridyl ethers

\begin{tabular}{cccc}
\hline \multirow{2}{*}{ Compound } & $\begin{array}{c}\text { Dose } \\
(\mu \mathrm{g} / \text { larva })\end{array}$ & \multicolumn{2}{c}{$\begin{array}{c}\text { Larval period } \\
\text { (Days } \pm \text { S.D. })\end{array}$} \\
\cline { 3 - 4 } & 10 & $3.1 \pm 0.3$ & $4.6 \pm 0.9$ \\
$\mathbf{1 9}$ & 100 & $3.4 \pm 0.5$ & $4.5 \pm 0.6$ \\
& 10 & $3.1 \pm 0.3$ & $4.2 \pm 0.6$ \\
$\mathbf{2 0}$ & 100 & $3.5 \pm 0.5$ & $4.6 \pm 0.9$ \\
\multirow{2}{*}{$\mathbf{2 1}$} & 10 & $4.1 \pm 0.3^{\mathrm{a}}$ & $5.1 \pm 0.6^{\mathrm{a}}$ \\
& 100 & $3.7 \pm 0.5^{\mathrm{a}}$ & $4.8 \pm 0.5^{\mathrm{a}}$ \\
\multirow{2}{*}{ Control } & & $3.2 \pm 0.4$ & $4.3 \pm 0.5$ \\
\hline
\end{tabular}

"Significant difference from the control value $(p<0.05)$.

not clear whether or not the prolongation of $3 \mathrm{rd}$ and 4 th periods is due to the anti-JH action of ETB. Compounds 1-4 which have a partial structure of JH mimics such as a phenoxyphenoxy or benzyloxyphenoxy group did not show any effect on larval growth or molting, resulting in molting into the 5 th instar similar to that of the control (data not shown). Compound $\mathbf{5}$ with a phenoxyphenoxy group at $10 \mu \mathrm{g}$ did not delay the $3 \mathrm{rd}$ ecdysis, but prolonged the duration of the 4 th larval period. Compounds 6 and $\mathbf{7}$ at $100 \mu \mathrm{g}$ delayed the 4 th ecdysis by an approximately half day compared with that of control, while at a low dose of $10 \mu \mathrm{g}$, they had no influence on larval growth.

Pyridyl ethers 12-17 irrespective of the position of the nitrogen atom did not cause any delay of larval growth (data not shown). 2-Methyl-5-pyridyl ether 21, which showed precocious metamorphosis-inducing activity, significantly prolonged the duration of the instar from 3 rd to 4 th, being comparable to that of ETB (Table 3). 6-Methyl-2-pyridyl ether 19 and 5-chloro-2-pyridyl ether $\mathbf{2 0}$ was inactive, suggesting that the presence of a 
methyl substituent on the 6-position of 3-pyridine ring is essential for activity. Although the precocious metamorphosis-inducing activity of compound $\mathbf{2 1}$ was weak, a series of 2-methyl-5-pyridyl ether is worthy of further investigation for new insect grow regulators.

\section{REFERENCE}

Baldwin, J. J., P. K. Lumma, G. S. Ponticello, F. C. Novello and J. M. Sprague 1977 Chlorosulfonation of 2-arylimidazoles. J. Heterocyclic Chem., 14: 889-892

Edwards, J. P., B. J. Bergot and G. B. Staal 1983 Effects of three compounds with anti-juvenile hormone activity and a juvenile hormone analogue on endogenous juvenile hormone levels in the tobacco hornworm, Manduca sexta. J. Insect Physiol., 29: 83-89

Kadono-Okuda, K., E. Kuwano, M. Eto and O. Yamashita 1987 Inhibitory action of an imidazole compound on ecdysone synthesis in prothoracic glands of the silkworm, Bombyx mori. Develop. Growth and Differ., 29: 527-533

Kiguchi, K., T. Mori and H. Akai 1984 Effects of anti-juvenile hormone "ETB" on the development and metamorphosis of the silkworm, Bombyx mori. J. Insect Physiol, 30: 499-506

Kuwano, E., Y. Tanaka, M. Kikuchi and M. Eto 1988 Effects of anti juvenile hormone and related compounds on development in the larvae of Bombyx mori. J. Fac. Agr., Kyushu Univ., 33: 17-28

Staal, G. B. 1982 Insect control with growth regulators interfering with the endocrine system. Entomol. Exp. Appl., 31: 15-23

Staal, G. B. 1986 Anti juvenile hormone agents, Ann. Rev. Entomol., 31: 391-429

Yoshida, T., T. Shiotsuki and E. Kuwano 2000 Synthesis and precocious metamorphosis-inducing activity of 3-(1-alkenyl)pyridines. J. Pesticide Sci., 25: 253-258 